\title{
The primary prevention in the service of addiction
}

Vasilios Koutras

From $1^{\text {st }}$ International Congress on Neurobiology and Clinical Psychopharmacology and European

Psychiatric Association Conference on Treatment Guidance

Thessaloniki, Greece. 19-22 November 2009

Taking into consideration the aetiology of drug use, primary prevention programs should enhance protective factors and reverse or reduce risks factors, address all forms of drug abuse, and be tailored to address risks specific to population or audience characteristics.

There are three types of prevention approaches defined in terms of population and risk factors. Universal prevention strategies apply to the general population of youth, regardless of individual risk, and aim to deter the onset of substance abuse. Selective prevention strategies target youth who are at greater risk because of their environment. Indicated prevention strategies are directed toward youth who are already using drugs or exhibiting individual and personal risk factors of drug use, such as thrill seeking, aggression, or conduct disorders.

Universal, selective, and indicated preventive interventions are defined by their specific targets, however, all universal, selective, and indicative preventive efforts may be categorized as school-based, family or communityfocused.

Published: 22 April 2010

doi:10.1186/1744-859X-9-S1-S18

Cite this article as: Koutras: The primary prevention in the service of addiction. Annals of General Psychiatry 2010 9(Suppl 1):S18.

Counseling Center for Combating Drug Abuse (S.S.K.N.N.I.) and University of loannina, Department of Preschool Education, Greece

๑ 2009 Koutras; licensee BioMed Central Ltd.
Submit your next manuscript to BioMed Central and take full advantage of:

- Convenient online submission

- Thorough peer review

- No space constraints or color figure charges

- Immediate publication on acceptance

- Inclusion in PubMed, CAS, Scopus and Google Scholar

- Research which is freely available for redistribution

Submit your manuscript at www.biomedcentral.com/submit
C Biomed Central 